\title{
PENGARUH TINGKAT KECUKUPAN MODAL DAN DANA PIHAK KETIGA TERHADAP PEMBIAYAAN BERBASIS BAGI HASIL
}

\author{
RIYAN BAGUS KRISTADA, ANI KUSUMANINGSIH \\ Universitas Pamulang \\ riyan.kristada@gmail.com
}

\begin{abstract}
The research examined influence of the level of capital adequacy and the third party funds to the profit based financing. This study uses Sharia Banks listed on the Financial Services Authority during the period 2013-2017 as the object of research. The research used quantitative. Source of data used is secondary data. Population of the research is Sharia Banks listed on the Financial Services Authority during the period 2013-2017. Determination of this research sample using purposive sampling method and obtained 5 Sharia Banks as samples. Technical data analysis used in this research is descriptive statistic test, classical assumption test, multiple linear regression analysis and hypothesis test using SPSS version 22. The research showed that: the level of capital adequacy has a significant positive to the profit based financing, the third party funds has a significant positive to the profit based financing. And also the level of capital adequacy and the third party funds has a significant effect to the profit based financing.
\end{abstract}

Keywords: The Level of Capital Adequacy, Third Party Funds, The Profit Based Financing.

\section{PENDAHULUAN}

\section{Latar Belakang Penelitian}

Berdasarkan UU No.10 tahun 1998 tentang Perbankan, "Bank adalah badan usaha yang menghimpun dana dari masyarakat dalam bentuk simpanan dan menyalurkannya kepada masyarakat dalam bentuk pembiayaan dan bentuk-bentuk lainnya dalam rangka meningkatkan taraf hidup rakyat banyak". Dengan demikian, bank merupakan bagian dari lembaga keuangan yang memiliki fungsi intermediasi, yaitu menghimpun dana dari masyarakat yang kelebihan dana dan menyalurkannya kepada masyarakat yang kekurangan dana.

Dalam dunia perbankan terdapat perbankan konvensional dan perbankan syariah. Pengertian perbankan syariah menurut UU No. 21 tahun 2008 adalah; "Segala sesuatu yang menyangkut tentang Bank Umum Syariah dan Unit Usaha Syariah, mencakup kelembagaan, kegiatan usaha, serta cara dan proses dalam melaksanakan kegiatan usahanya". Bank Syariah adalah bank yang menjalankan 
kegiatan usahanya berdasarkan prinsip syariah dan menurut jenisnya terdiri atas Bank Umum Syariah (BUS) dan Bank Pembiayaan Rakyat Syariah (BPRS). Sedangkan Unit Usaha Syariah (UUS) adalah unit kerja dari kantor pusat bank umum konvensional yang berfungsi sebagai kantor induk dari kantor atau unit yang melaksanakan kegiatan usaha berdasarkan prinsip syariah, atau unit kerja di kantor cabang dari suatu bank yang berkedudukan di luar negeri yang melaksanakan kegiatan usaha secara konvensional yang berfungsi sebagai kantor induk dari kantor cabang pembantu syariah dan/atau unit syariah. "Perbankan syariah menggunakan prinsip syariah di mana aturan perjanjian didasarkan pada hukum Islam antara bank dan pihak lain untuk penyimpanan dana, pembiayaan kegiatan usaha atau kegiatan lainnya yang sesuai dengan syariah" (Yanis dan Priyadi, 2015). "Bank sekaligus dapat menjalankan pola pembiayaan syariah yang terbagi ke dalam empat kategori yang dibedakan berdasarkan tujuan penggunannya. Pertama, pembiayaan dengan prinsip jual beli. Kedua, pembiayaan dengan prinsip sewa. Ketiga pembiayaan dengan prinsip bagi hasil. Keempat, pembiayaan dengan akad pelengkap" (Karim, 2007). Dengan tersedianya berbagai macam pilihan produk yang ditawarkan bank syariah, salah satu jenis pembiayaan yang idealnya menjadi produk utama adalah pembiayaan bagi hasil mudharabah dan musyarakah.

Penyaluran dana bank syariah melalui pembiayaan berbasis bagi hasil dapat dipengaruhi oleh beberapa faktor yaitu faktor internal yang dapat dilihat dalam laporan keuangan masing-masing perbankan syariah, dan faktor eksternal yang dapat dilihat pada kondisi makro ekonomi di Indonesia (Nurrochman, 2016). Untuk dapat menyalurkan pembiayaan bank memerlukan sumber dana. Salah satu sumber dana perbankan yang terbesar berasal dari dana pihak ketiga. "Dana-dana yang dihimpun dari masyarakat merupakan sumber dana terbesar yang paling diandalkan oleh bank (Dendawijaya, 2005:35)". Penelitian ini akan menggunakan data laporan keuangan perbankan Bank Umum Syariah yang terdaftar di Otoritas Jasa Keuangan (OJK) selama periode 2013-2017 sebagai objek penelitian.

Berdasarkan latar belakang di atas, maka judul penelitian ini adalah:

\section{"Pengaruh Tingkat Kecukupan Modal dan Dana Pihak Ketiga terhadap Pembiayaan Berbasis Bagi Hasil".}

\section{Perumusan Masalah}

Berdasarkan permasalahan yang menjadi latar belakang subjek penelitian, maka rumusan masalah yang diajukan dalam penelitian ini adalah :

1. Apakah tingkat kecukupan modal berpengaruh terhadap pembiayaan berbasis bagi hasil?

2. Apakah dana pihak ketiga berpengaruh terhadap pembiayaan berbasis bagi hasil?

3. Apakah tingkat kecukupan modal dan dana pihak ketiga berpengaruh terhadap pembiayaan berbasis bagi hasil? 


\section{Tujuan Penelitian} bertujuan :

Berdasarkan latar belakang dan rumusan masalah di atas, penelitian ini

1. Untuk mengetahui dan memberi bukti empiris pengaruh tingkat kecukupan modal terhadap pembiayaan berbasis bagi hasil;

2. Untuk mengetahui dan memberi bukti empiris pengaruh dana pihak ketiga terhadap pembiayaan berbasis bagi hasil;

3. Untuk mengetahui dan memberi bukti empiris pengaruh tingkat kecukupan modal dan dana pihak ketiga terhadap pembiayaan berbasis bagi hasil.

\section{LANDASAN TEORI DAN HIPOTESIS}

\section{Teori Stewardship}

Menurut Donaldson dan Davis (1991) dalam Choirudin (2017), "Teori stewardship merupakan teori yang menggambarkan situasi di mana para manajer tidaklah termotivasi oleh tujuan-tujuan individu tetapi lebih ditujukan kepada sasaran hasil utama mereka untuk kepentingan organisasi, sehingga teori stewardship mempunyai dasar psikologi dan sosiologi yang telah dirancang di mana para eksekutif sebagai steward termotivasi untuk bertindak sesuai keinginan prinsipal, selain itu perilaku steward tidak akan meninggalkan organisasinya sebab steward berusaha mencapai sasaran organisasinya". Pada teori stewardship, model of man ini didasarkan pada pelayan yang memiliki perilaku dimana dia dapat di bentuk agar selalu bisa diajak bekerjasama dalam sebuah organisasi, memiliki perilaku kolektif atau berkelompok dengan utilitas tinggi daripada individunya dan selalu bersedia untuk melayani.

\section{Perbankan Syariah}

Berdasarkan UU No. 21 tahun 2008 mengenai Perbankan Syariah, "Perbankan syariah adalah bank yang menjalankan kegiatan usahanya berdasarkan prinsip syariah dan menurut jenisnya terdiri dari Bank Umum Syariah dan Bank Pembiayaan Rakyat Syariah". Dalam undang-undang tersebut memuat juga mengenai asas, tujuan, fungsi, badan hukum dan berbagai hal yang berkaitan dengan perbankan syariah.

\section{Pembiayaan Bank Syariah}

Bank syariah dalam menjalankan fungsinya terdapat dua hal utama yang harus dijalankan, yaitu menghimpun dana untuk pemenuhan kebutuhan akan dana dan menyalurkan dana yang didapat kepada masyarakat dalam bentuk pembiayaan. Pembiayaan atau financing yang dikenal juga dengan sebutan kredit adalah pendanaan yang diberikan oleh suatu pihak kepada pihak lain untuk mendukung investasi yang telah direncanakan. Tujuan dari pembiayaan sendiri ada berbagai macam diantaranya membantu dalam peningkatan ekonomi umat, menyediakan dana untuk kebutuhan pengembangan usaha, memberikan peluang bagi masyarakat untuk meningkatkan daya produksinya, membuka lapangan kerja 
baru dengan dibukanya sektor usaha melalui bantuan pembiayaan yang diberikan lembaga keuangan dan distribusi pendapatan lebih merata.

Menurut Karim (2005), pembiayaan syariah dibagi menjadi 6 jenis, yaitu pembiayaan modal kerja syariah, pembiayaan investasi syariah, pembiayaan konsumtif syariah, pembiayaan sindikasi, pembiayaan berdasarkan take over, dan pembiayaan letter of credit. Dalam akad pembiayaan istilah laba tidak asing lagi, karena dalam akad pembiayaan tujuannya adalah saling mendapatkan keuntungan atau laba sesuai dengan prinsip bagi hasil.

\section{Pembiayaan Berbasis Bagi Hasil}

Bank syariah muncul pertama kali dengan membawa label bagi hasil, hal itu juga yang menjadi pembeda dengan bank konvensional. Dalam keseluruhan produk bank syariah menerapkan sistem bagi hasil dalam operasionalnya dan diharapkan dapat menjadi produk utama bank syariah. Melihat fungsi bank syariah yaitu dalam upaya menyalurkan dana ke masyarakat melalui bentuk pembiayaan, khususnya dalam bentuk pembiayaan berbasis bagi hasil.

Bagi hasil sendiri adalah bentuk pengembalian (return) dari kontrak investasi. Pembiayaan bagi hasil terdiri dari 4 akad, yaitu musyarakah, mudharabah, musaqah dan muzara ${ }^{e e}$ ah. Tetapi dalam operasional bank syariah sendiri yang banyak digunakan adalah akad musyarakah dan mudharabah. Jenis dari bagi hasil sendiri terbagi menjadi dua jenis yaitu dengan cara profit sharing dan revenue sharing. Pada saat ini, umumnya bank syariah menggunakan revenue sharing dalam pembagian bagi hasil (Fitria, 2017)". Dari penjelasan di atas dapat disimpulkan bahwa pembiayaan berbasis bagi hasil merupakan suatu pendanaan yang diberikan oleh pihak pemilik modal kepada pihak yang membutuhkan dana dalam rangka mendukung usaha yang telah direncanakan dengan berasaskan pada sistem bagi hasil. Pada bank syariah, ada dua jenis pembiayaan dengan prinsip bagi hasil yaitu pembiayaan mudharabah dan musyarakah.

\section{Pembiayaan Musyarakah}

Musyarakah adalah akad kerjasama antara dua pihak atau lebih untuk suatu usaha tertentu, di mana masing-masing pihak memberikan kontribusi dana dengan ketentuan bahwa keuntungan dibagi berdasarkan kesepakatan sedangkan kerugian berdasarkan porsi kontribusi dana berupa kas maupun aset non kas yang diperkenankan oleh syariah. Akad musyarakah terbagi menjadi beberapa jenis yang di antaranya ada syirkah al-'Inan, syirkah mufawadhah, syirkah A'maal, syirkah wujuh dan ada pula syirkah al-mudarabah. Dalam perbankan syariah biasanya diaplikasikan ke dalam pembiayaan suatu usaha atau proyek dan sebagai modal ventura. Banyak manfaat yang didapat dari pembiayaan dengan akad musyarakah bagi pihak bank maupun pihak nasabah. Salah satu manfaat bagi pihak nasabah adalah pengembalian pokok pembiayaan disesuaikan dengan arus usaha nasabah sehingga tidak memberatkan nasabah dalam hal pengembalian pokok pembiayaan.

"Dalam sistem pembiayaan seperti ini ketika bank benar-benar menginginkan keuntungan yang riil dan dapat dibagi nantinya, maka bank harus selektif dan berhati-hati dalam memilih nasabah. Tentunya akan dicari nasabah 
yang menjalankan sebuah usaha yang halal, aman dan juga menguntungkan (Antonio, 2009)". Dalam musyarakah, dapat ditemukan aplikasi ajaran islam tentang ta'awun (gotong royong), ukhuwah (persaudaraan) dan keadilan. Keadilan sangat terasa dalam penentuan nisbah untuk pembagian keuntungan yang bisa saja berbeda dari porsi modal sebelumnya, hal ini bisa disebabkan karena ada faktor lain, misalnya keahlian, pengalaman, ketersedian waktu dan sebagainya. Selain itu keuntungan yang dibagikan pada pemilik modal merupakan keuntungan riil, bukan merupakan nilai nominal yang telah ditetapkan sebelumnya seperti bunga dan riba. Prinsip keadilan juga dirasa ketika orang yang punya modal lebih besar akan menanggung risiko finansial yang juga lebih besar.

\section{Pembiayaan Mudharabah}

Mudharabah juga merupakan salah satu akad bentuk pembiayaan dengan prinsip bagi hasil. Akad ini merupakan suatu bentuk kerja sama antar dua pihak atau lebih dimana pemilik dana atau yang sering disebut dengan shahibul maal menyedikan $100 \%$ dana yang nantinya akan dipercayakan kepada si pemilik usaha atau mudharib dan keuntungan akan dibagi sesuai kesepakatan. "Di dalam akad mudharabah, masalah risiko akan ditanggung oleh si pemilik dana kecuali ketika risiko yang muncul tersebut merupakan akibat dari kelalaian pihak pengelola dana. Untuk itu diharapkan pengelola dana atau mudharib mampu mengoptimalkan laba dan menimimalisir adanya risiko yang dapat timbul sewaktu-waktu (Karim, 2004)".

\section{Tingkat Kecukupan Modal}

"Peraturan Bank Indonesia Nomor:10/15/ PBI/2008 tentang Kewajiban Penyediaan Modal Minimum Bank Umum Bab I Pasal 2 menyatakan bahwa bank wajib menyediakan modal minimum sebesar 8\% (delapan persen) dari Aset Tertimbang Menurut Risiko (ATMR). Modal bank dibagi kedalam modal inti dan modal pelengkap (Muhammad, 2002:215 217)".

\section{Dana Pihak Ketiga}

Menurut UU No. 21 Tahun 2008 tentang Perbankan Syariah (Pasal 1), "Simpanan adalah dana yang dipercayakan oleh Nasabah kepada Bank Syariah dan/atau UUS berdasarkan akad wadi'ah atau akad lain yang tidak bertentangan dengan prinsip syariah dalam bentuk giro, tabungan, atau bentuk lainnya yang dipersamakan dengan itu".

\section{METODE RISET}

\section{Jenis Penelitian}

Jenis data yang digunakan dalam penelitian ini adalah dengan menggunakan metode penelitian Kuantitatif. Data Kuantitatif adalah data yang berupa angka-angka dan menganalisis menggunakan statistik (Sugiyono, 2016: 7). 


\section{Lokasi Penelitian}

Penelitian ini dilakukan di Bank Umum Syariah yang terdaftar di OJK dengan mengunduh data laporan keuangan perbankan syariah dari situs resmi OJK melalui website www.ojk.go.id. Objek penelitian ini adalah Bank Umum Syariah yang terdaftar di OJK pada tahun 2014-2017.

\section{Variabel dan Pengukurannya}

Menurut Sugiyono (2009:3), variabel penelitian adalah segala sesuatu yang berbentuk apa saja yang ditetapkan oleh peneliti untuk dipelajari sehingga diperoleh informasi tentang hal tersebut kemudian ditarik kesimpulannya. Penelitian ini ditentukan oleh dua variabel yaitu dependen, dan variabel independen.

\section{Variabel Dependen}

Variabel dependen sering disebut sebagai variabel output, kriteria, konsekuen atau sering disebut variabel terikat (Sugiyono, 2016:39). Variabel dependen yang digunakan dalam penelitian ini adalah pembiayaan berbasis bagi hasil. berikut :

Pembiayaan berbasis bagi hasil dapat diukur dengan perhitungan sebagai

$$
\text { Pembiayaan Berbasis Bagi Hasil = Musyarakah }+ \text { Mudharabah }
$$

\section{Variabel Independen}

Variabel independen (variabel bebas) ini sering disebut sebagai variabel stimulus, predictor, antecedent (Sugiyono, 2016: 39). Variabel independen dalam penelitian ini adalah tingkat kecukupan modal dan dana pihak ketiga.

1. Tingkat Kecukupan Modal

Tingkat kecukupan modal diproksikan dengan capital adequacy ratio (CAR) yang merupakan alat analisis yang digunakan untuk mengetahui berapa jumlah modal yang memadai untuk menunjang kegiatan operasionalnya dan cadangan untuk menyerap kerugian yang mungkin terjadi.

$$
C A R=\frac{\text { Modal }}{\text { Aktiva Tertimbang Menumut Resiko (ATMR) }} \times 100 \%
$$

\section{Dana Pihak Ketiga}

Penghimpunan dana masyarakat di perbankan syariah menggunakan instrumen yang sama dengan penghimpunan dana pada bank konvensional, yaitu instrumen giro, tabungan, dan deposito. Ketiga instrumen ini biasa disebut dengan istilah dana pihak ketiga (Jamilah, 2016).

Dana Pihak Ketiga = Giro + Deposito + Tabungan

\section{Populasi dan Sampel}

Populasi adalah wilayah generalisasi yang terdiri atas obyek/subjek yang mempunyai kualitas dan karakteristik tertentu yang ditetapkan oleh peneliti untuk 
dipelajari kemudian ditarik kesimpulannya (Sugiyono, 2016:80). Populasi dalam penelitian ini adalah seluruh bank umum syariah di Indonesia yang terdaftar di lembaga Otoritas Jasa Keuangan (OJK). Berdasarkan data statistik laporan perbankan dari Otoritas Jasa Keuangan (www.ojk.go.id) terdapat 13 Bank Umum Syariah

Berdasarkan populasi dari 13 Bank Umum Syariah yang ada, diperoleh 4 data penelitian dari satu Bank Umum Syariah dalam jangka waktu 1 tahun. Dengan penggabungan data 13 Bank Umum Syariah dalam jangka waktu penelitian 5 tahun, maka diperoleh total populasi sebanyak 260 data.

Sampel adalah bagian dari jumlah dan karakteristik yang dimiliki oleh populasi (Sugiyono, 2016: 81). Pengambilan sampel perusahaan dalam penelitian ini menggunakan metode purposive sampling. Dalam Indriantoro dan Supomo (2002) teknik purposive sampling merupakan tipe pemilihan sampel secara tidak acak yang informasinya diperoleh dengan menggunakan pertimbangan/kriteria tertentu. Adapun kriteria-kriteria tersebuat adalah sebagai berikut :

1. Bank Umum Syariah di Indonesia yang terdaftar di website OJK sampai dengan 31 Desember 2017.

2. Bank Umum Syariah yang mempublikasikan laporan keuangan dan laporan rasio keuangan setiap triwulan secara berturut-turut selama periode 2013-2017.

3. Bank Umum Syariah yang menjadi sampel harus mempunyai data pembiayaan berbasis bagi hasil yang berasal dari laporan keuangan triwulanan secara berturut-turut selama periode 2013-2017.

4. Bank Umum Syariah yang menjadi sampel harus mempunyai data CAR yang berasal dari laporan kualitas aset produktif setiap triwulan selama periode 2013-2017.

5. Bank Umum Syariah yang menjadi sampel harus mempunyai data dana pihak ketiga yang berasal dari laporan keuangan triwulanan secara berturut-turut selama periode 2013-2017.

Berdasarkan kriteria pemilihan sampel yang telah disebutkan maka sampel yang digunakan dalam penelitian ini sebanyak 5 Bank Umum Syariah, yaitu Bank Syariah Mandiri, Bank BNI Syariah, Bank BRI Syariah, Bank Bukopin Syariah, dan Bank Panin Dubai Syariah. Berdasarkan sampel diperoleh 4 data penelitian dari satu Bank Umum Syariah selama 1 tahun dari laporan keuangan triwulanan, sehingga diperoleh sampel sebanyak 20 data per tahunnya dari satu Bank Umum Syariah. Dari data 5 Bank Umum Syariah selama 5 tahun, maka diperoleh sampel sebanyak 100 data yang digunakan dalam penelitian ini dari total 260 data populasi.

\section{Teknik Pengumpulan Data}

Data yang digunakan dalam penelitian ini ada data sekunder berupa laporan keuangan Bank Umum Syariah yang terdaftar di Otoritas Jasa Keuangan (OJK). Dalam penelitian ini data yang diperoleh adalah Statistik Perbankan Syariah (SPS) pada tahun 2013-2017 yang diakses melalui website resmi Otoritas Jasa Keuangan (OJK) www.ojk.go.id. 


\section{Teknik Analisis Data}

Pada umumnya teknik pengambilan sampel dilakukan dengan cara acak, teknik pengumpulan data menggunakan instrumen metode penelitian kuantitatif, analisa data yang bersifat kuantitatif atau statistik bertujuan untuk menguji hipotesis yang ditetapkan (Sugiyono, 2016).

\section{Statistik Deskriptif}

Menurut (Ghozali, 2016) statistik deskriptif memberikan gambaran atau deskripsi suatu data yang dilihat dari nilai rata-rata (mean), standar deviasi, varian, maksimum, minimum, sum, range, kurtosis, dan skewness (kemencangan distribusi).

\section{Uji Asumsi Klasik}

Tujuan uji asumsi klasik dalam penelitian ini adalah untuk menguji apakah data memenuhi asumsi klasik. Hal ini untuk menghindari terjadinya estimasi yang bias karena tidak semua data dapat diterapkan regresi. Penelitian ini menggunakan uji normalitas, uji multikolineritas, uji heterokedastisitas, dan uji autokorelasi.

\section{Analisis Regresi Berganda}

Analisis ini dilakukan secara kuantitatif dengan bantuan statistik, analisis regresi berganda (multiple regresion analysis) dengan tujuan mengetahui apakah variabel bebas memiliki pengaruh yang signifikan terhadap variabel terikat.

$$
\begin{array}{ll}
\mathrm{Y}=\alpha+\beta \mathrm{X} 1+\beta 2 \mathrm{X} 2+\varepsilon \\
\text { Keterangan: } & \\
\mathrm{Y} & =\text { Pembiayaan Berbasis Bagi Hasil } \\
\alpha & =\text { Konstanta Regresi } \\
\beta, \beta 2 & =\text { Koefisien Regresi } \\
\mathrm{X} 1 & =\mathrm{CAR} \\
\mathrm{X} 2 & =\mathrm{DPK} \\
\mathrm{E} & =\text { Standar Error }
\end{array}
$$

\section{Koefisien Determinasi (R2)}

Nilai R2 digunakan untuk mengukur seberapa jauh kemampuan model dalam menerangkan variasi variabel dependen. Nilai koefisien determinasi berkisar antara nol dan satu. Nilai R2 yang kecil berati kemampuan variabel-variabel dalam menjelaskan variabel dependen amat terbatas. Nilai yang mendekati 1 berarti variabel-variabel independen memberikan semua informasi yang dibutuhkan untuk memprediksi variasi variabel dependen (Ghozali, 2016:95).

\section{Uji Signifikansi Simultan (Uji Statistik F)}

Menurut Ghozali (2016) uji F pada dasarnya menunjukkan apakah semua variable bebas yang dimasukkan dalam model mempunyai pengaruh secara bersama-sama terhadap variable terikat.

\section{Uji Signifikansi Parameter Individual (Uji Statistik t)}

Uji t pada dasarnya menunjukkan seberapa jauh pengaruh satu variable penjelasan atau independen secara individual dalam menerangkan variasi 
variable dependen (Ghozali, 2016). Pengujian dilakukan dengan menggunakan signifikansi level $0.05(\alpha=5 \%)$.

\section{ANALISIS DATA DAN PEMBAHASAN}

\section{Gambaran Umum Objek Penelitian}

Penelitian ini menggunakan data kuantitatif berupa laporan keuangan dan laporan rasio keuangan setiap triwulan yang diperoleh dari website resmi Otoritas Jasa Keuangan (OJK) yaitu www.ojk.go.id. Populasi dalam penelitian ini adalah Bank Umum Syariah yang terdaftar di Otoritas Jasa Keuangan periode 2013-2017.

\section{Deskripsi Sampel}

Pemilihan sampel dalam penelitian ini menggunakan teknik purposive sampling dengan kriteria tertentu. Berdasarkan data dari OJK pada tahun 20132017, populasi bank umum syariah sebanyak 13 bank. Berdasarkan kriteria yang telah ditetapkan pada bab sebelumnya, diperoleh jumlah sampel sebanyak 5 Bank Umum Syariah, yaitu:

Tabel 4.1 Daftar Objek Penelitian

\begin{tabular}{|c|l|}
\hline No. & \multicolumn{1}{|c|}{ Nama Bank } \\
\hline 1 & Bank Syariah Mandiri \\
\hline 2 & Bank Negara Indonesia Syariah \\
\hline 3 & Bank Rakyat Indonesia Syariah \\
\hline 4 & Bank Bukopin Syariah \\
\hline 5 & Bank Panin Dubai Syariah \\
\hline
\end{tabular}

\section{Analisis Statistik Deskriptif}

Analisis statistik deskriptif dapat dilihat pada tabel 4.2 sebagai berikut:

\section{Tabel 4.2 Hasil Uji Statistik Deskriptif}

\begin{tabular}{|l|r|r|r|r|r|}
\hline & $\mathrm{N}$ & \multicolumn{1}{l}{ Minimum } & Maximum & \multicolumn{1}{c|}{ Mean } & \multicolumn{1}{c|}{$\begin{array}{c}\text { Std. } \\
\text { Deviation }\end{array}$} \\
\hline CAR & 100 & 10.74 & 31.15 & 164.194 & 382.199 \\
LN_DPK & 100 & 14.26 & 18.17 & 163.889 & 104.468 \\
LN_PBH & 100 & 13.45 & 16.86 & 152.278 & .80485 \\
Valid N (listwise) & 100 & & & & \\
\hline
\end{tabular}

Sumber : Data sekunder diolah, 2019

Berdasarkan hasil uji statistik deskriptif pada tabel 4.2 menunjukkan bahwa banyaknya jumlah data penelitian $(\mathrm{N})$ adalah 100. Dari hasil uji statistik deskriptif di atas dapat dilihat nilai minimum, maksimum, rata-rata dan standar deviasi dari variabel CAR sebagai proksi dari tingkat kecukupan modal, LN DPK (dana pihak ketiga) dan LN PBH (pembiayaan berbasis bagi hasil). 


\section{Uji Asumsi Klasik}

Uji asumsi klasik yang digunakan dalam penelitian ini adalah uji normalitas, uji multikolinearitas, uji heteroskedastisitas dan uji autokorelasi.

1. Uji Normalitas

Tujuan dilakukannya uji normalitas adalah untuk menguji apakah dalam model regresi, residual memiliki distribusi normal. Caranya dengan menggunakan normal probability plot, dan uji kolmogorov-smirnov (K-S). Hasil dari pengujian normal $P$-P Plot dapat dilihat pada gambar berikut ini :

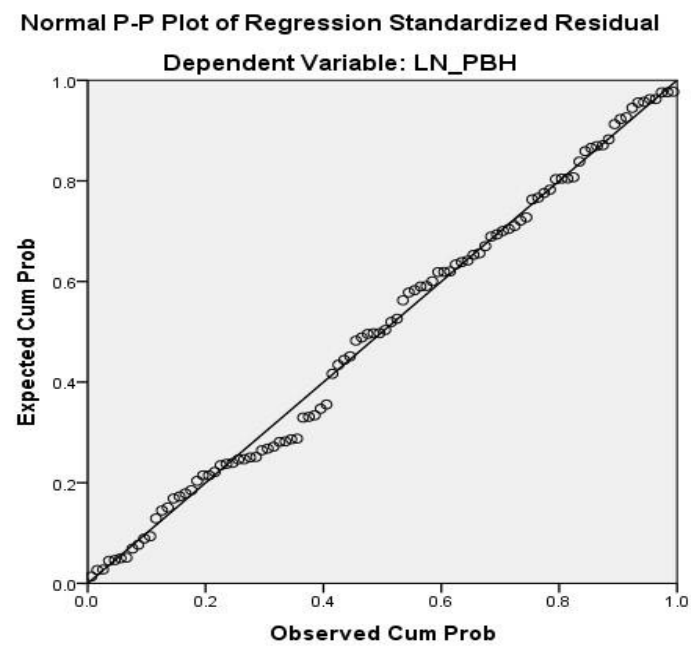

Gambar 4.1 Grafik P-Plot

Dari grafik normal plot pada gambar 4.1 dapat disimpulkan bahwa analisis kurva menunjukkan model regresi memenuhi asumsi normalitas.

\section{Tabel 4.3 Hasil Uji Normalitas Menggunakan Uji Kolmogorov-Smirnov}

\begin{tabular}{|ll|r|}
\hline & & Unstandardized Residual \\
\hline N & & 100 \\
Normal Parameters & Mean & .0000000 \\
& Std. Deviation & .36090464 \\
Most Extreme Differences & Absolute & .075 \\
& Positive & .075 \\
& Negative & -.039 .075 \\
Test Statistic & & $.179^{c}$ \\
Asymp. Sig. (2-tailed) & & \\
\hline
\end{tabular}

Sumber : Data sekunder diolah, 2019

Pengujian normalitas dengan menggunakan Kolmogorov memliki syarat yaitu apabila probabilitas $>0,05$ hipotesis 0 diterima karena data berdistribusi secara normal. Berdasarkan tabel 4.3, hasil uji normalitas menggunakan uji statistik non-parametrik kolmogorov-smirnov diperoleh nilai Asymp. Sig. (2tailed) sebesar 0,179, di mana nilai 0,179>0,05 sehingga dapat disimpulkan data yang digunakan dalam penelitian ini telah terdistribusi dengan normal. 
2. Uji Multikolinearitas

Uji multikolinearitas bertujuan untuk menguji apakah pada model regresi ditemukan adanya korelasi antar variabel independen (bebas). Model regresi yang baik adalah tidak terjadi korelasi antar variabel independen (bebas). Untuk mendeteksi ada tidaknya multikolinearitas dapat dilihat dari nilai tolerance dan variance inflation factor (VIF). Jika nilai tolerance lebih besar dari 0,10 dan nilai variance inflation factor (VIF) lebih kecil dari 10 maka tidak terjadi multikolinearitas terhadap data yang di uji. Berikut ini adalah tabel hasil pengujian multikolinearitas dengan menggunakan nilai tolerance dan nilai VIF:

Tabel 4.4 Hasil Uji Multikolinearitas Menggunakan VIF Coefficients $^{a}$

\begin{tabular}{|c|c|c|c|c|c|c|c|}
\hline \multirow[t]{2}{*}{ Model } & \multicolumn{2}{|c|}{ Unstandardized Coefficients } & Standardized Coefficients & \multirow[t]{2}{*}{$t$} & \multirow[t]{2}{*}{ Sig. } & \multicolumn{2}{|c|}{ Collinearity Statistics } \\
\hline & $\mathrm{B}$ & Std. Error & Beta & & & \begin{tabular}{l|l} 
Tolerance \\
\end{tabular} & VIF \\
\hline 1 (Constant) & 3.034 & .714 & & 4.249 & .000 & & \\
\hline CAR & .061 & .012 & .290 & 5.158 & .000 & .664 & 1.506 \\
\hline LN DPK & .660 & .041 & .857 & 16.193 & .000 & .748 & 1.336 \\
\hline
\end{tabular}

Sumber : Data sekunder diolah, 2019

Dari tabel 4.4 di atas menunjukkan bahwa semua variabel independen memiliki nilai tolerance $>0,1$ dan nilai variance inflation factor (VIF) $<10$. Berdasarkan tabel 4.4 diperoleh hasil nilai toleransi 0,664; $0,748>0,10$ dan nilai VIF 1,506; 1,336 < 10, sehingga dapat disimpulkan data yang digunakan pada penelitian ini terbebas dari masalah multikolinearitas.

3. Uji Autokorelasi

Uji Autokorelasi bertujuan untuk mengetahui apakah ada korelasi antara anggota serangkaian data observasi yang diuraikan menurut waktu (timeseries) atau ruang (cross section). Beberapa penyebab munculnya masalah autokorelasi dari sebagian data time series dalam analisis regresi adalah adanya kelembaman (inertia) artinya data observasi pada periode sebelumnya dan periode sekarang kemungkinan besar akan mengandung saling keuntungan (interdependence). Uji Durbin-Watson (Uji D-W) merupakan uji yang sangat popular untuk menguji ada tidaknya masalah autokorelasi dari model empiris yang diestimasi. Berikut adalah hasil dari uji autokorelasi :

Tabel 4.5 Hasil Uji Autokorelasi Model Summary ${ }^{b}$

\begin{tabular}{|l|r|r|r|r|r|}
\hline \multicolumn{1}{|c|}{ Model } & $\mathrm{R}$ & R Square & Adjusted R Square & $\begin{array}{r}\text { Std. Error of } \\
\text { the Estimate }\end{array}$ & Durbin-Watson \\
\hline 1 & $.894^{\mathrm{a}}$ & .799 & .793 & .36650 & .329 \\
\hline
\end{tabular}

a. Predictors: (Constant), LN_DPK, CAR

b. Dependent Variable: LN_PBH

Sumber : Data sekunder diolah, 2019

Salah satu ukuran dalam menentukan ada tidaknya masalah autokorelasi dengan uji Durbin- Watson (DW) dengan ketentuan tidak terjadi autokorelasi, 
jika nilai DW berada di antara -2 dan +2 . Berdasarkan tabel 4.5 di atas, diketahui nilai Durbin Watson sebesar 0.329 yang berarti berada diantara -2 dan +2 , sehingga dapat disimpulkan data dalam penelitian ini tidak ada masalah autokorelasi.

4. Uji Heteroskedastisitas

Uji heteroskedastisitas bertujuan untuk menguji apakah dalam model regresi terjadi ketidaksamaan variance dari residual satu pengamatan ke pengamatan lain. Jika variance dari residual satu pengamatan ke pengamatan lain tetap, maka disebut homokedastisitas dan jika berbeda disebut heteroskedastisitas. Dalam penelitian ini untuk mendeteksi ada atau tidaknya heteroskedastisitas atau homokedastisitas menggunakan metode analisis grafik scatterplot.

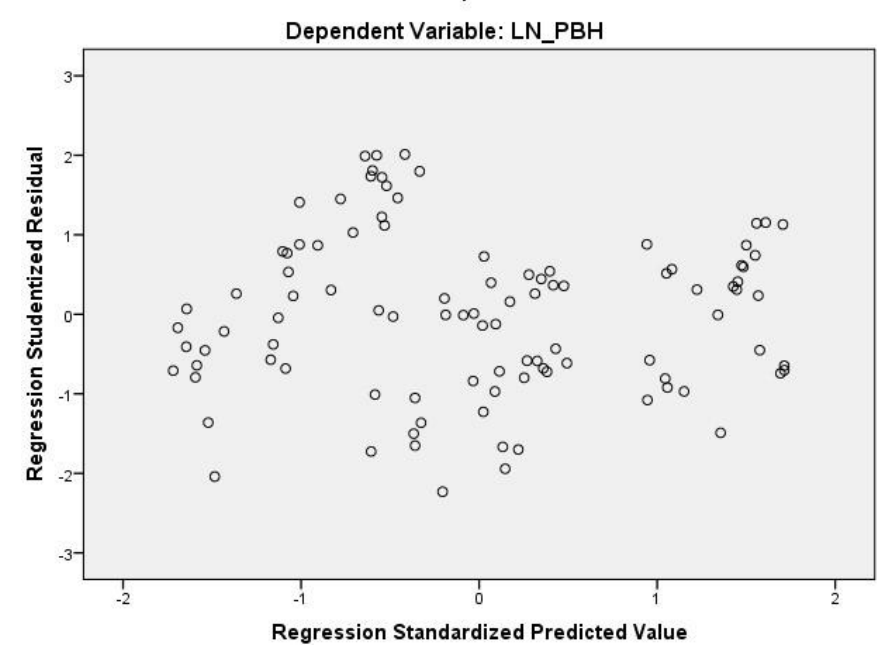

Gambar 4.2 Grafik Scatterplot

Berdasarkan hasil grafik scatterplot pada gambar 4.2 di atas, terlihat bahwa titik-titik menyebar secara acak dan membentuk pola yang tidak teratur di atas dan di bawah angka 0 pada sumbu Y, maka dapat disimpulkan bahwa model regresi tidak terjadi heterokedastisitas.

\section{Analisis Regresi Linier Berganda}

Uji regresi linier berganda dimaksudkan untuk melihat pengaruh tingkat kecukupan modal, tingkat pembiayaan bermasalah dan dana pihak ketiga terhadap pembiayaan berbasis bagi hasil. Analisis regresi berganda bertujuan menghitung besarnya pengaruh dua atau lebih variabel bebas terhadap satu variabel terikat dan memprediksi variable terikat dengan menggunakan dua atau lebih variabel bebas. Analisis ini untuk memprediksi nilai dari variabel dependen apabila nilai variabel independen mengalami kenaikan atau penurunan.

Bentuk sebuah persamaan untuk menguji hipotesis pada penelitian ini adalah sebagai berikut : 
Tabel 4.6 Hasil Uji Regresi Linear Berganda

Coefficients $^{a}$

\begin{tabular}{|c|c|c|c|c|c|}
\hline \multirow[t]{2}{*}{ Model } & \multicolumn{2}{|c|}{ Unstandardized Coefficients } & Standardized Coefficients & \multirow[t]{2}{*}{$\mathrm{t}$} & \multirow{2}{*}{ Sig. } \\
\hline & $\mathrm{B}$ & Std. Error & Beta & & \\
\hline 1 (Constant) & 3.034 & .714 & & 4.249 & .000 \\
\hline CAR & .061 & .012 & .290 & 5.158 & .000 \\
\hline LN DPK & .660 & .041 & .857 & 16.193 & .000 \\
\hline
\end{tabular}

a. Dependent Variable: LN_PBH

Sumber : Data sekunder diolah, 2019

Berdasarkan hasil pengujian regresi pada tabel 4.6 di atas maka dapat dibentuk sebuah persamaan sebagai berikut:

$$
Y=3,034+0.061 X 1+0,660 X 2+\varepsilon
$$

berikut:

Interprestasi atas persamaan regresi tersebut dapat dinyatakan sebagai

1. Konstanta sebesar 3,034 menyatakan bahwa jika CAR (X1), dan dana pihak ketiga (X2) konstan atau tidak ada atau 0 , maka nilai pembiayaan berbasis bagi hasil sebesar 3,034.

2. Koefisien regresi CAR (X1) sebesar 0,061 menyatakan bahwa setiap penambahan 1 poin CAR (X1), maka pembiayaan berbasis bagi hasil akan cenderung naik sebesar 0,061 .

3. Koefisien regresi dana pihak ketiga (X2) sebesar 0,660 menyatakan bahwa setiap penambahan atau 1 poin dana pihak ketiga (X2), maka pembiayaan berbasis bagi hasil akan cenderung naik sebesar 0,660 .

\section{Koefisien Determinasi $\left(\mathbf{R}^{2}\right)$}

Koefisien determinasi (R2) pada intinya mengukur seberapa jauh kemampuan model dalam menerangkan variasi variabel dependen. Hasil uji koefisien determinasi antara terhadap kecurangan laporan keuangan (akrual modal kerja) dapat dilihat pada tabel 4.7 di bawah ini:

Tabel 4.7 Hasil Uji Koefisien Determinasi $\left(\mathbf{R}^{2}\right)$

\begin{tabular}{|c|c|c|c|c|}
\hline \multicolumn{5}{|c|}{ Model Summary } \\
\hline Model & $\mathrm{R}$ & R Square & Adjusted R Square & $\begin{array}{l}\text { Std. Error of } \\
\text { the Estimate }\end{array}$ \\
\hline 1 & $.894^{\mathrm{a}}$ & .799 & .793 & .36650 \\
\hline
\end{tabular}

a. Predictors: (Constant), LN_DPK, CAR

Sumber : Data sekunder diolah, 2019

Berdasarkan tabel 4.7 di atas menunjukkan bahwa nilai R Square adalah 0,799 atau sebesar $79,9 \%$. Hal ini berarti $79,9 \%$ dari variabel dependen yaitu pembiayaan berbasis bagi hasil dapat dijelaskan atau dipengaruhi oleh variabel independen yaitu tingkat kecukupan modal (CAR), dan dana pihak ketiga. Sedangkan sisanya sebesar $20,1 \%$ dijelaskan oleh variabel lain yang tidak diteliti dalam penelitian ini. 


\section{Uji Signifikan Parameter Individual (Uji Statistik t)}

Uji statistik t digunakan untuk mengetahui apakah variabel independen dalam penelitian ini yaitu CAR sebagai proksi dari tingkat kecukupan modal, dan dana pihak ketiga secara parsial atau individual mempengaruhi variabel dependen, yaitu pembiayaan berbasis bagi hasil. Adapun tingkat signifikan yang digunakan pada penelitian ini yaitu 0,05. Berikut ini adalah tabel hasil uji statistik t :

Tabel 4.8 Hasil Uji Statistik t

Coefficients $^{a}$

\begin{tabular}{|c|c|c|c|c|c|}
\hline \multirow[t]{2}{*}{ Model } & \multicolumn{2}{|c|}{ Unstandardized Coefficients } & \multirow{2}{*}{$\begin{array}{c}\text { Standardized Coefficients } \\
\text { Beta }\end{array}$} & \multirow[t]{2}{*}{$t$} & \multirow[t]{2}{*}{ Sig. } \\
\hline & \begin{tabular}{c|}
$\mathrm{B}$ \\
\end{tabular} & Std. Error & & & \\
\hline 1 (Constant) & 3.034 & .714 & & 4.249 & .000 \\
\hline CAR & $.061 \mid$ & .012 & .290 & 5.158 & .000 \\
\hline LN DPK & .660 & .041 & .857 & 16.193 & .000 \\
\hline
\end{tabular}

a. Dependent Variable: LN_PBH

Sumber : Data sekunder diolah, 2019

Berdasarkan tabel 4.8 di atas, diperoleh hasil sebagai berikut :

1. Variabel CAR sebagai proksi dari tingkat kecukupan modal memiliki t test (thitung) sebesar 5,158 dengan tingkat signifikansi sebesar 0,000 $(0,000<$ $0,05)$. Hal ini menunjukkan bahwa variabel tingkat kecukupan modal (CAR) memiliki pengaruh positif secara signifikan terhadap pembiayaan berbasis bagi hasil. Dengan demikian berarti bahwa $\mathrm{H} 1$ diterima.

2. Variabel dana pihak ketiga memiliki t test (thitung) sebesar 16,193 dengan tingkat signifikansi sebesar $0,000 \quad(0,000<0,05)$. Hal ini menunjukkan bahwa variabel dana pihak ketiga memiliki pengaruh positif secara signifikan terhadap pembiayaan berbasis bagi hasil. Dengan demikian berarti bahwa $\mathrm{H} 2$ diterima.

\subsubsection{Uji Signifikansi Simultan (Uji Statistik f)}

Uji statistik f digunakan untuk mengetahui apakah variabel independen dalam penelitian ini yaitu CAR sebagai proksi dari tingkat kecukupan modal dan dana pihak ketiga secara simultan mempengaruhi variabel dependen, yaitu pembiayaan berbasis bagi hasil. Adapun tingkat signifikan yang digunakan pada penelitian ini yaitu 0,05 . Berikut ini adalah hasil uji statistik f:

Tabel 4.9 Hasil Uji Statistik f ANOVA $^{\mathrm{a}}$

\begin{tabular}{|c|c|c|c|c|c|}
\hline Model & $\begin{array}{l}\text { Sum of } \\
\text { Squares }\end{array}$ & $d f$ & Mean Square & $F$ & Sig. \\
\hline 1 Regression & 51.235 & 3 & 17.078 & 127.144 & \multirow[t]{3}{*}{$.000^{b}$} \\
\hline Residual & 12.895 & $96 \mid$ & .134 & & \\
\hline Total & 64.130 & 99 & & & \\
\hline
\end{tabular}

a. Dependent Variable: LN PBH

b. Predictors: (Constant), LN_DPK, CAR, NPF

Sumber : Data sekunder diolah, 2019 
Berdasarkan tabel 4.9 nilai f hitung sebesar 127,144 dengan nilai signifikan 0.000. Karena nilai signifikansi lebih kecil dari 0,05 $(0,000<0,05)$ maka H3 diterima. Hasil tersebut menunjukkan bahwa variabel independen, yaitu CAR sebagai proksi dari tingkat kecukupan modal dan dana pihak ketiga secara simultan memiliki pengaruh terhadap pembiayaan berbasis bagi hasil.

\subsection{Diskusi Hasil dan Pembahasan}

Pembahasan dalam penelitian ini bertujuan untuk menjelaskan hasil dari penelitian sesuai dengan tujuan penelitian. Hasil penelitian diperoleh sebagai berikut:

\subsubsection{Pengaruh Tingkat Kecukupan Modal terhadap Pembiayaan Berbasis Bagi Hasil}

Berdasarkan hasil pengujian yang telah dilakukan, hasil penelitian ini menunjukkan bahwa CAR sebagai proksi dari tingkat kecukupan modal berpengaruh signifikan terhadap pembiayaan berbasis bagi hasil. Hal ini dilihat dari nilai signifikansi sebesar $0,000<0,05$ dan nilai t-hitung sebesar 5,158. Hal ini menunjukkan bahwa hipotesis pertama $(\mathrm{H} 1)$ memiliki pengaruh secara parsial terhadap pembiayaan berbasis bagi hasil. Dengan demikian hipotesis pertama pada penelitian ini diterima.

Hasil penelitian ini konsisten dengan penelitian yang dilakukan oleh Ahmad Choirudin (2017) dan Jamilah (2016) yang menemukan bahwa CAR sebagai proksi dari tingkat kecukupan modal berpengaruh terhadap pembiayaan berbasis bagi hasil. Hal ini menunjukkan bahwa CAR sebagai proksi dari tingkat kecukupan modal memiliki pengaruh yang positif dan signifikan terhadap pembiayaan berbasis bagi hasil dikarenakan tingkat kecukupan modal bank berbanding lurus terhadap besar kecilnya pembiayaan berbasis bagi hasil yang disalurkan oleh bank syariah. Bank syariah yang memiliki modal yang besar dapat menggunakan modal tersebut secara efektif dan optimal untuk menghasilkan pendapatan bagi bank yang berasal dari jumlah pembiayaan berbasis bagi hasil yang meningkat. Pengaruh besarnya modal terhadap peningkatan penyaluran pembiayaan berbasis bagi hasil juga menunjukkan bahwa bank-bank syariah yang beroperasi pada tahun tersebut mengoptimalkan modal yang ada.

\subsubsection{Pengaruh Dana Pihak Ketiga terhadap Pembiayaan Berbasis Bagi Hasil}

Berdasarkan hasil pengujian yang telah dilakukan, hasil penelitian ini menunjukkan bahwa dana pihak ketiga berpengaruh signifikan terhadap pembiayaan berbasis bagi hasil. Hal ini dilihat dari nilai signifikansi sebesar 0,000 $<0,05$ dan nilai t-hitung sebesar 16,193. Hal ini menunjukkan bahwa hipotesis kedua (H2) memiliki pengaruh secara parsial terhadap pembiayaan berbasis bagi hasil. Dengan demikian hipotesis kedua pada penelitian ini diterima.

Hasil penelitian ini konsisten dengan penelitian yang dilakukan oleh Isnu Nurrochman (2016), Hafidh Wahyu Purnomo dan Arief Lukman Santoso (2015), Jamilah (2016), dan Nurraini Indah Arum Fitria (2017) yang menemukan bahwa dana pihak ketiga memiliki pengaruh yang positif dan signifikan terhadap 
pembiayaan berbasis bagi hasil. Hal ini karena dana pihak ketiga menjadi sumber pendanaan utama bagi bank syariah dalam menghimpun dana. Oleh karena itu, bank syariah akan memanfaatkan penghimpunan dana yang besar melalui dana pihak ketiga untuk meningkatkan penyaluran pembiayaan berbasis bagi hasil sehingga semakin tinggi dana pihak ketiga, maka semakin tinggi penyaluran pembiayaan berbasis bagi hasil.

\subsubsection{Pengaruh Tingkat Kecukupan Modal dan Dana Pihak Ketiga terhadap Pembiayaan Berbasis Bagi Hasil}

Berdasarkan hasil pengujian secara simultan atau secara bersama-sama yang telah dilakukan, hasil penelitian ini menunjukkan bahwa variabel independen dalam penelitian ini secara simultan berpengaruh signifikan terhadap pembiayaan berbasis bagi hasil. Hal ini dilihat dari nilai signifikansi sebesar $0.000<0.05$ dan nilai f-hitung sebesar 127,144. Hal ini menunjukkan bahwa hipotesis ketiga (H3) memiliki pengaruh secara simultan terhadap pembiayaan berbasis bagi hasil.

Dengan demikian hipotesis ketiga dalam penelitian ini diterima.

\section{KESIMPULAN}

\subsection{Kesimpulan}

Berdasarkan analisis dan pembahasan pada Bank Umum Syariah yang terdaftar di Otoritas Jasa Keuangan (OJK) tahun 2013-2017, maka dapat diambil kesimpulan sebagai berikut:

1. Tingkat kecukupan modal yang diproksikan dengan Capital Adequacy Ratio $(C A R)$ berpengaruh positif secara signifikan terhadap pembiayaan berbasis bagi hasil, maka $\mathrm{H} 1$ diterima.

2. Dana pihak ketiga berpengaruh positif secara signifikan terhadap pembiayaan berbasis bagi hasil, maka $\mathrm{H} 2$ diterima.

3. Tingkat kecukupan modal, tingkat pembiayaan bermasalah, dan dana pihak ketiga secara simultan berpengaruh terhadap pembiayaan berbasis bagi hasil, maka $\mathrm{H} 3$ diterima.

\subsection{Saran}

Bertolak pada keterbatasan yang dihadapi peneliti pada studi ini, maka dapat diberikan beberapa saran guna meningkatkan mutu penelitian selanjutnya, yaitu:

1. Penelitian selanjutnya diharapkan dapat menggunakan populasi yang lebih banyak dengan menambah Unit Usaha Syariah (UUS), sehingga memperoleh hasil yang lebih maksimal.

2. Dapat menambah sampel data lebih banyak lagi dengan menambah tahun pengamatan agar data yang didapatkan lebih baik dari sebelumnya.

3. Peneliti selanjutnya diharapkan dapat menemukan variabel proksi lain yang mempengaruhi pembiayaan berbasis bagi hasil, seperti Financing To Deposit 
Ratio (FDR), Biaya Operasional Pendapatan Operasional (BOPO), dan Return On Asset (ROA).

\section{DAFTAR PUSTAKA}

Ana, Leni Tantri dan Umiyati (2017), Faktor-Faktor yang Mempengaruhi Pembiayaan Pada Bank Umum Syariah Devisa di Indonesia, Jurnal Ekonomi dan Perbankan Syariah, Vol. 5. No.1, 2017.

Choirudin, Ahmad, (2017), Analisis Faktor yang mempengaruhi Pembiayaan Bagi Hasil Mudharabah pada Bank Umum Syariah di Indonesia, Surabaya.

Fitria, Nurraini Indah Arum (2017), Pengaruh Kecukupan Modal, Non Performing Financing, Dana Pihak Ketiga dan Inflasi Terhadap Pembiayaan Bank Syariah di Indonesia, Salatiga.

Ghozali, Imam (2016), Aplikasi analisis multivariate dengan program IBM SPSS 23, Badan Penerbit Universitas Diponegoro.

Hidayat, A. (2020). Pengaruh penggunaan aplikasi eviews terhadap kemampuan pemecahan masalah dan hasil belajar statistik. MAJU: Jurnal Ilmiah Pendidikan Matematika, 7(1), 18-24.

Hidayat, A., \& Sadewa, P. (2020). Pengaruh Penggunaan Aplikasi Eviews Terhadap Sikap Belajar dan Kemampuan Pemecahan Masalah Statistik. Edumaspul: Jurnal Pendidikan, 4(1), 321-328.

Iskandar (2008), Metodologi Penelitian Pendidikan dan Sosial (Kuantitatif dan Kualitatif), Jakarta: Gaung Persada Press.

Ismail, (2011), Perbankan Syariah, Jakarta: Kencana.

Jamilah (2016), Faktor-faktor yang Mempengaruhi Pembiayaan Mudharabah Pada Bank Umum Syariah di Indonesia, Jurnal Ilmu dan Riset Akuntansi Vol 5 No. 4, 2016.

Karim, Adiwarman (2004), Bank Islam: Analisis Fiqih Keuangan, Jakarta: PT. Raja Grafindo Persada.

Kasmir (2008), Bank dan lembaga Keuangan Lainnya, Jakarta: Rajawali Press.

Kasmir (2014), Analisis Laporan Keuangan, Jakarta: Rajawali Press.

Muhammad (2005), Bank Syariah, Problema dan Prospek di Indonesia, Yogyakarta: Graha Ilmu.

Nurrochman, Isnu (2016), Analisis Faktor-Faktor yang memengaruhi Pembiayaan pada Bank Umum Syariah (Studi pada Bank Umum Syariah Tahun 2012-2015), Fakultas Ekonomika dan Bisnis.

Rimadhani, M., dan Osni, E. (2011), Analisis Variabel-Variabel yang Mempengaruhi Pembiayaan Murabahah Pada Bank Syariah Mandiri Periode 2008 2011, Jurnal Ekonomi, Vol.19 No. 1, 2011.

Siamat, Dahlan (2004), Manajemen Lembaga Keuangan, Edisi Keempat, Jakarta: Fakultas Ekonomi Universitas Indonesia.

Sugiyono (2016), Metode Penelitian Kuantitatif, Kualitatif dan R\&D, Bandung: Alfabeta. 